\title{
研究論文
}

\section{ITER トロイダル磁場コイル用ラジアル・プレートの試作}

\author{
高野 克敏 $* 1, \dagger$, 小泉 徳潔*1, 清水 辰也 ${ }^{* 1}$, 中嶋 秀夫*1 \\ 江崎 康一 ${ }^{* 2}$, 長本 義史 ${ }^{* 2}$, 牧野 吉延 ${ }^{* 2}$
}

\section{Trial Manufacture of ITER Toroidal Field Coil Radial Plate}

\author{
Katsutoshi TAKANO ${ }^{* 1, \dagger}$, Norikiyo KoIZUMI ${ }^{* 1}$, Tatsuya SHIMIZU*1 ${ }^{* 1}$, Hideo NAKAJIMA ${ }^{* 1}$ \\ Koichi ESAKI ${ }^{* 2}$, Yoshifumi NAGAMOTO*2 and Yoshinobu MAKINO*2
}

\begin{abstract}
Synopsis: In an ITER toroidal field (TF) coil, tight tolerances of $1 \mathrm{~mm}$ in flatness and a few millimeters in profile are required to manufacture a radial plate (RP), although the height and width of the RP are $13 \mathrm{~m}$ and $9 \mathrm{~m}$, respectively. In addition, since cover plates (CPs) should be fitted to a groove in the RP with tolerance of $0.5 \mathrm{~mm}$, tight tolerances are also required for the CPs. The authors therefore performed preliminary and full-scale trials to achieve tight tolerances that meet the required RP manufacturing schedule, such as one RP every three weeks. Before the full-scale trials, preliminary trials were performed to optimize machining procedures, welding conditions and assembly procedures for the RP, and the manufacturing processes for the straight and curved CP segments. Based on these preliminary trial results, full-scale RP and CPs were fabricated. The flatness achieved for the RP is $1 \mathrm{~mm}$, except at the top and bottom where gravity support is insufficient. If the gravity support is suitable, it is expected that a flatness of $1 \mathrm{~mm}$ is achievable. The profile of the RP was measured to be within the targeted range, better than $2 \mathrm{~mm}$. In addition, most of the CPs fit the corresponding groove of the RP. Although the issue of hot-cracking in the weld still remains, the test results indicate that this problem can be prevented by improving the geometry of the welding joint. Thus, we can conclude that the manufacturing procedures for RP and CP have been demonstrated.
\end{abstract}

Keywords: ITER, TF coil, radial plate, cover plate, laser welding

\section{1. はじめに}

$\mathrm{TF}$ コイルの巻線部で使用するラジアル・プレート $(\mathrm{RP})^{1)}$ は、 長さ $13 \mathrm{~m}$ 、幅 $9 \mathrm{~m}$ 、厚さ $10 \mathrm{~cm}$ の大型構造物であるにも拘らず、 平面度で $1 \mathrm{~mm}$ 、輪郭度で $2 \mathrm{~mm}$ の高精度の製作公差が要求 されている。また、RP の溝の中に導体を挿入し、導体を固定す るために、RP 溝にカバー・プレート $(\mathrm{CP})$ といら蓋をする。CP は RP とレーザー溶接するため、 CP と RP 間のギャップを $0.5 \mathrm{~mm}$ 以下に管理する必要がある。このため、RP と CP は高い寸法精 度で製作する必要がある。ただし、実機 TF コイルの製作では、 3 週間に 1 枚の RP を製作する必要があり、RP の製作は、効

Received November 30, 2011

The views and opinions expressed herein do not necessarily reflect those of the ITER Organization.

*1 日本原子力研究開発機構

干311-0193 茨城県那珂市向山 801-1

Japan Atomic Energy Agency, 801-1 Mukoyama, Naka, Ibaraki 311-0193, Japan

*2 株式会社東芝 電力システム社

干230-0045 神奈川県横浜市鶴見区未広 2-4

Toshiba Cooperation, Power systems company, 2-4, Suehiro,

Tsurumi-ku, Yokohama, Kanagawa 230-0045, Japan

† E-mail: takano.katsutoshi@jaea.go.jp
率的手法を採用する必要がある。

一方、後述のように、RP の製作方法には、材料製作も含め て複数種あり、著者らは、RP 製作技術の開発を効率的に進め、 かつ、技術開発に失敗した場合のリスクを低減するめに、TF コ イルの調達を担当する日本と欧州で複数の異なる製作方法を 分担して開発することとした。実機 RP の製作は、これらの結果 を基に、最も合理的な方法で製作を進める計画である。

本論文では、始めに RP 及び CP の要求性能を説明し、続 いて、日欧で分担した RP の製作技術を紹介する。これらに引 続き、日本が実施した中規模及び実規模の試作結果について 報告する。

\section{2. $\mathrm{RP}$ 及び $\mathrm{CP}$ の要求性能}

RP は、Fig. 1 に示すように、その上下面に $\mathrm{Nb}_{3} \mathrm{Sn}$ 超伝導生 成熱処理 (約 $650^{\circ} \mathrm{C}$ ) を施した巻線導体を収納するための螺旋 状の溝を設けたステンレス鋼製の構造物である。RP には断面 が対称な標準 RP(rRP) と非対称な側面 RP(sRP)があり、5 枚 の rRP を用いて製作した標準ダブル・パンケーキ $(\mathrm{rDP})$ を 2 枚 の sRP を用いて製作した sDP で挟み込んで $\mathrm{TF}$ コイル巻線部 となる。 

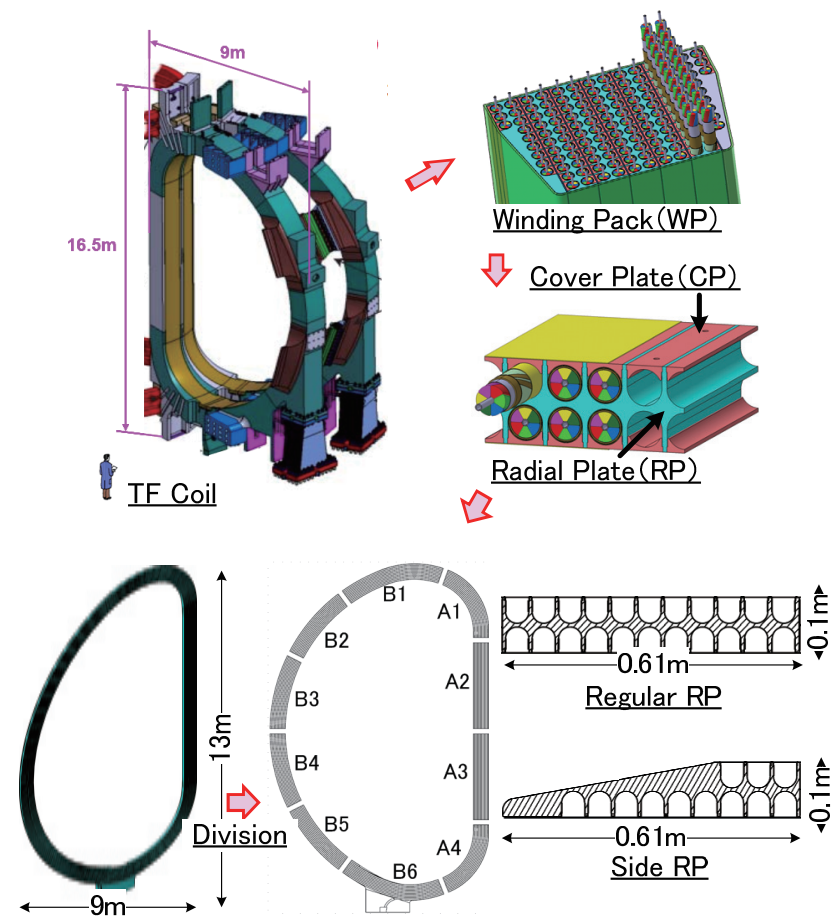

Radial Plate(RP) RP Segument Name

Fig. 1 ITER TF coil RP and CP. The left bottom figure shows 3 dimensional schema of RP. The right bottom figures are crosssectional view of the rRP and sRP at the inboard. An RP is segmented into 10 sections as may be seen in the middle bottom figure. These sections are made in parallel and then assembled by welding.

Table 1 ITER TF coil RP and CP, and the required tolerances

\begin{tabular}{|c|c|c|c|c|c|}
\hline & \multicolumn{3}{|c|}{ Radial Plate } & \multicolumn{2}{c|}{ Cover Plate } \\
\hline Item & Flatness & Profile & Groove Cross Section & Curvature & Cross Section \\
\hline Torerance & $1 \mathrm{~mm}$ & $2 \mathrm{~mm}$ & $\pm 0.1 \mathrm{~mm}$ & $0.3 \mathrm{~mm}$ & $\pm 0.1 \mathrm{~mm}$ \\
\hline
\end{tabular}

また、rRP では片面 11 溝、両面で 22 溝の溝があり、sRP に は片面にそれぞれ 9 溝と 3 溝ある。これらの溝に熱処理後の 導体を、超伝導性能を劣化させないように、過剩な歪を加える ことなくスムーズに挿入する必要がある。さらに、導体挿入時の 導体絶縁層の損傷も避ける必要がある。このため、Table 1 に 示すように、RP の寸法管理は重要であり、RP の各溝の平均周 長として、公差 $\pm 0.01 \%$ を満足することを目標とした。周長公差 $\pm 0.01 \%$ 達成するために、RP の輪郭度は $2 \mathrm{~mm}$ となる。また、 7 枚の DP を積層して 1 体の巻線部を形成するため、DP の平 面度として $2 \mathrm{~mm}$ が要求され、 $\mathrm{CP}$ 溶接による面外変形 ${ }^{2)}$ 考 慮し、RP の平面度としては $1 \mathrm{~mm}$ を達成する必要がある。

RP に使用寸る材料は、要求される応力区分に応じて JSME 規格「核融合設備規格 超伝導マグネット構造規格 2008 (JSME 規格)」 ${ }^{3)}$ で規定されている SUS316LN をベースと する 3 種類のオーステナイト系ステンレス(炭素含有量十窒素 含有量 $(\mathrm{C}+\mathrm{N})>0.20 \%$ : FM316LNH 、 $\mathrm{C}+\mathrm{N}>0.15 \%$ : FM316LNM、C+N>0.10\%:FM316LNL)である。

一方、 CP の形状は、RP の溝形状にあわせて、直状、一様
曲率の円弧状、及び曲率が遷移する曲線状の 3 種類がある。 製作した CP は RP 溝に挿入し、RP の歯とレーザー溶接するた め、 $\mathrm{CP}$ と RP 間の隙間(ギャップ)を $0.5 \mathrm{~mm}$ 以下とする必要が ある ${ }^{2)}$ 。このため、CP は断面形状で $\pm 0.1 \mathrm{~mm}$ 、曲率部の曲率半 径の精度は $\pm 0.3 \mathrm{~mm}$ で製作する必要がある。

\section{3. 日本と欧州の技術開発協力}

日本と欧州は、2 項で述べた高精度の RP 製作公差に対し、 要求を満足する効率的な製作方法を分担 ${ }^{4)}$ 七開発すること で、効率的に試作を進め、開発に伴うリスク低減を図ることとし た。また、rRP と sRP では個別の技術課題が有るため、日欧で $\mathrm{rRP}$ とRP の製作技術を分担して開発することとした。

RP の製作は、 3 週間に 1 枚のペースで完了寸る必要がある ため、RP を分割して、セグメント化し、各 RP セグメントを並行し て機械加工にて製作し、これらの RP セグメントを溶接で組立て る必要がある。そこで、適用可能な技術としては、以下が考えら れた。

1) 材料

2 項に示す要求を満足する厚肉ステンレス鋼の製作方法とし ては、圧延、鍛造、及びステンレス鋼の粉末を熱間等方圧加圧 法 (HIP)により、RP セグメントの最終形状に近いプリフォーム ド・セグメントを製作する方法が候補として挙げられた。

2) 溶接組立

RP セグメントの溶接組立方法としては、Tungsten Inert Gas (TIG) 溶接、電子ビーム $(\mathrm{EB})$ 溶接、及びレーザー溶接が候補 として挙げられた。前二者では継手形状を矩形とするため、溶 接が効率的に、かつ容易に行えるが、RP の組立後、溶接部に 溝を設けるための機械加工を実施する必要があり、これによる RP 全体の変形が危惧された。一方、レーザー溶接では、溝加 工を完了した溶接継手を溶接できるため、溶接後の機械加工 を避けることができる。

3) セグメント製作

RP は極めて高精度の公差が要求されているため、セグメント 製作は機械加工とした。ただし、後述のように、溶接組立後に 最終機械加工を実施する案も採用されたため、セグメント加工 を仕上げ加工前までとする方法も候補とした。さらに、前述のよ うに、溶接部の継手形状も 2 種類考えられたので、端部形状が 異なるセグメントが候補として挙げられた。

4) 最終加工

TIG 溶接では、溶接変形が大きくなるため、全体組立後に最 終機械加工を実施する案が採用された。なお、本手法は、RP に寸法矯正が必要となった場合のバック・アップの役割も兼ね ている。

上記の製作技術に対する日欧の開発分担を Table 2 にまと めた。日本では、Table 2 に示すように、RPを 10 分割したセグ メントを最終断面形状に機械加工し、これらのセグメントを D 型 に配置して、レーザー溶接で組み立てる方法を採用した。 
Table 2 Matrix of EU-JA collaboration in challenging development of the RP manufacturing processes

\begin{tabular}{c|c|c|c}
\hline \hline \multirow{2}{*}{ RP type } & \multicolumn{2}{|c|}{ JAEA } & \multicolumn{2}{c}{ EU } \\
& \multicolumn{2}{|c|}{ Regular RP } & Side RP \\
\hline Plate & Hot-rolling & HIPing & Forging \\
\hline Sections & 10 & 16 & 7 \\
\hline Welding & Laser & TIG & EB \\
\hline Joint of RP & Welding & $\begin{array}{c}\text { Welding and } \\
\text { local } \\
\text { machining }\end{array}$ & $\begin{array}{c}\text { Welding and final } \\
\text { machining }\end{array}$ \\
\hline \hline
\end{tabular}

本製作方法の利点としては、前述のように、最終断面形状ま で仕上がった RP セグメントを接続するため、溶接後の機械加 工は不要となるとともに、溶接後の機械加工による変形を防止 できる。

一方、課題としては、U 溝形状をした継手部をレーザー溶接 で接続するため、溶接条件を連続的に変化させる必要があり、 溶接割れが懸念された。また、レーザー溶接ができるように RP セグメント間のギャップ管理が求められ、高精度な開先合せ (フィッティング)が可能な治工具が必要となる。

本稿では、欧州で実施した試作結果については紹介までと し、日本が実施した試作結果について次項以降に記述する。

\section{4. 溶接試験}

RP の組立ては、前述のように、最終断面形状まで機械加工 した 10 個の RP セグメントを D 型に配置し、レーザー溶接で接 続して組立てるため、以下の項目について技術的な検証試験 を行った。

1）溶接欠陥の無い、溶接条件の確立。

2) レーザー溶接を可能にするために、各セグメント間の溶接 部のギャップを高精度に管理するための治工具の開発。

3） 10 個の RP セグメントを D 型に溶接組立するときに溶接変 形が発生しにくい溶接手順の把握、及び溶接変形の予測 方法の確立。

これらの技術検証のために、1）に関しては 4.1 項の溶接性 試験、2) については 4.2 項の 22 溝溶接試験、及び、3) につ いては 4.3 項の平板溶接試験を実施した。これらの試験の詳 細について以下に記す。

\section{1 溶接性試験}

溶接性を確認するため、最終断面形状を模擬した U 溝形状 の試験体 (Fig. 2) を用いて溶接性試験を実施した。本試験で 使用した試験体の化学組成を Table 3、溶接条件を Fig. 3 に 示す。

断面マクロ、放射性透過試験 (RT)、超音波探傷試験 (UT)

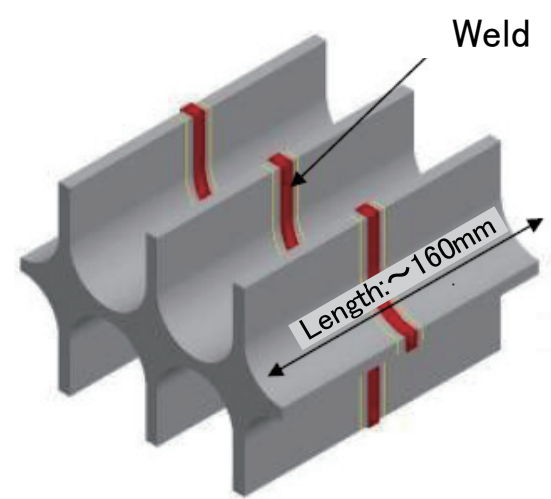

Fig. 2 Welding test specimen.

Table 3 Chemical composition of material used in the welding test sample ( $\mathrm{wt} \%)$

\begin{tabular}{|c|c|c|c|c|c|c|c|c|c|}
\hline & C & Si & Mn & P & S & Ni & Cr & Mo & N \\
\hline FM316LNH & 0.02 & 0.19 & 1.62 & 0.021 & 0.001 & 10.73 & 18.3 & 2.08 & 0.21 \\
\hline
\end{tabular}
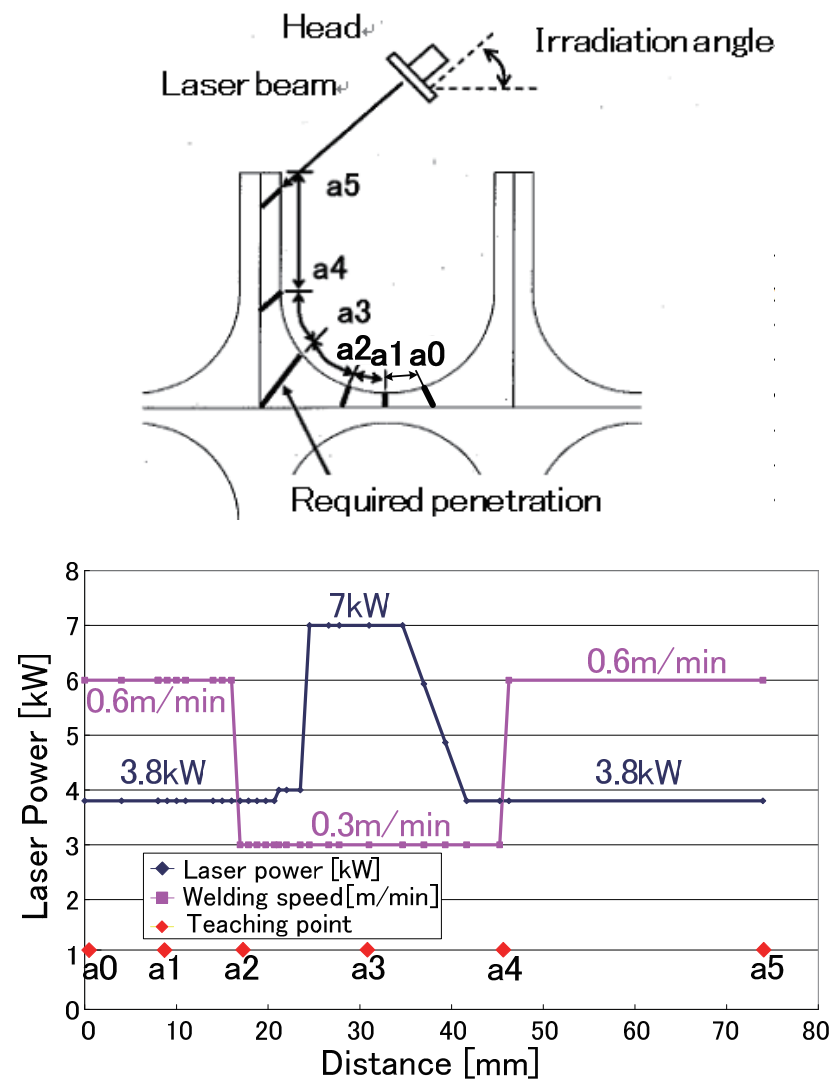

Fig. 3 Laser welding power as a function of position in the groove. Laser welding power and welding speed as a function of distance from the bottom of the groove, where is indicated by a1 in the upper figure. The upper figure indicates the location shown in the lower figure as ak $(\mathrm{k}=0-5)$.

の 3 種類の試験の結果、全ての試験において溶接割れが確 認された。このため、溶接割れを抑制するための試験として、以 下を実施した。 
1) レーザーの入射角度を溶接体に対して垂直となるような入 射角度の変更。

2) 溶接中の緩やかなレーザー出力の変化。

3）溶接中の緩やかな溶接速度の変更。

4) 溶接部にフェライトを含有したシムの挿入。

しかし、これらの試験の結果、RT では溶接割れは確認 されなかったが、断面マクロ観察の結果、全ての溶接条件 において溶接割れを検出した。

そこで、溶接割れの原因調查及び溶接割れ防止を目的 に、同材料を用いて 25〜30 $\mathrm{mm}$ の矩形の試験体に対し て、下向き溶接によるビードオン試験を実施した。試験で は、溶接出力を変化させた場合と出力を一定とした場合の 割れの発生の有無を評価した。試験の結果、出力が一定の 溶接条件では、凝固割れが検知されず、健全な溶接品質を 達成できることを確認した（Fig. 4）。しかし、U 溝形状 を模擬した溶接条件では、微細な溶接割れが発生すること が確認できた（Fig. 5）。この原因として、溶接条件が連 続的に変化し、溶接部に急激な入熱変化が起こったためと 推察される。

以上の試験結果により、最終断面形状での RP セグメン 卜の溶接では、その複雑な形状のため溶接割れの回避が難 しいと考えられる。一方、溶接条件を一定とした場合、す なわち、矩形断面形状をした溶接継手の場合には、溶接割 れを防止できることが分かった。ただし、本矩形断面形状 にも、前述のように溶接部の機械加工に伴う加工変形の課
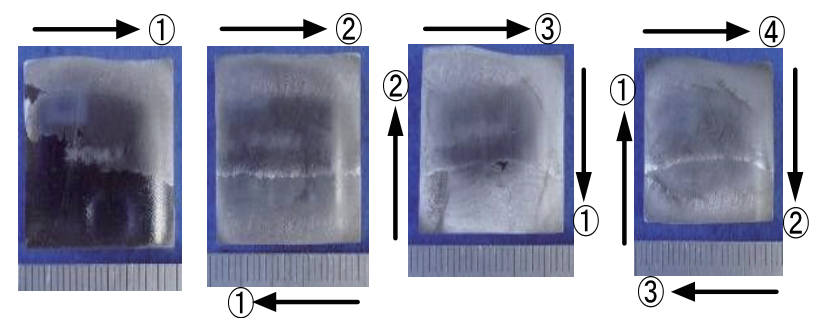

Fig. 4 Macro-graphic observation of welding using simple rectangular-shaped stainless steel plate $(25 \mathrm{~mm}$ in thickness and $30 \mathrm{~mm}$ in length). Welding power is a constant. A number in a circle indicates sequence of the welding.
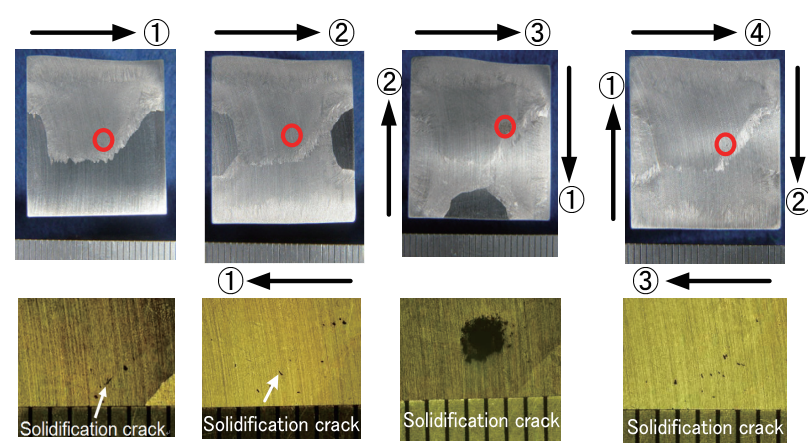

Fig. 5 Macro-graphic observation of welding using simple rectangular-shaped stainless-steel plate $(25 \mathrm{~mm}$ in thickness and $30 \mathrm{~mm}$ in length). Welding power was constant. A number in a circle indicates sequence of the welding.
題があり、この試験検証は欧州で実施することとしたた め、日本では Table 2 に示す開発分担に従って試作を進め ることとした。

\subsection{2 溝溶接試験}

RP セグメント間をレーザーで溶接するためには、1）両セグメ ントをギャップなく突き合わせることができる、2）溝を突き合わ せた場合のアライメントを調整できる、3）溶接による面外変形を 拘束できる、ことが重要であり、実機 RP 製作を想定し、Fig. 6 に 示す治具を製作した。また、溶接による収縮変形を抑制するた め、溶接手順についても最適化する必要がある。これらの検証 のために、Fig. 6 に示すような二つの短尺 RP セグメントを用い

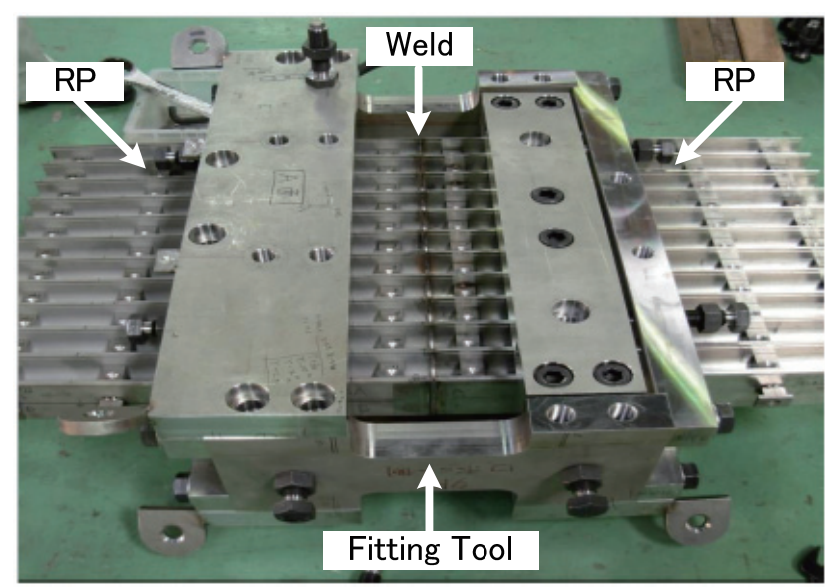

Fig. 6 Welding test between RP segments.

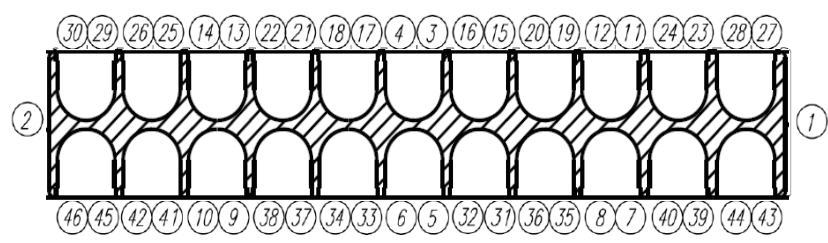

Fig. 7 Welding sequence for 22 grooves in a RP. A number in a circle indicates sequence of the welding.

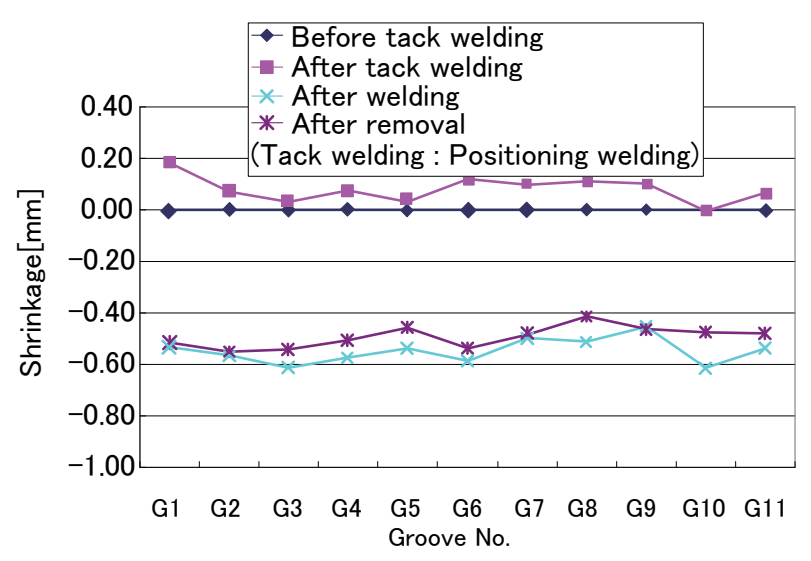

Fig. 8 Welding deformation measured for the sample shown in Fig. 6. 
た試作試験 5) として実施した。

試験手順としては :

1）二つの短尺 RP セグメントの開先面をレーザー溶接が可能 な $0.2 \mathrm{~mm}$ 以下のギャップとなるよう治工具を用いて フィッティング調整を行う。

2) セグメントの仮付け溶接を行う。

3) 本溶接の手順は、面内、面外変形を考慮し、断面内を バランスよく溶接する必要があるため、Fig. 7 に示す番 号の順序で 3 回の反転を行いながら溝を本溶接する。

試験の結果を Fig. 8 に示す。仮付け前の段階でギャップを $0.1 \mathrm{~mm}$ 以下の精度でフィッティングすることができ、溶 接による溶接部の横収縮量 (溝長手方向)を約 $0.5 \mathrm{~mm}$ 以下に 抑制することができた。さらに、溶接手順としてバランス溶接する ことにより、RP 縦収縮量（溝幅方向）、面内変形、面外変形 は測定誤差の範囲内であることを確認した。以上の成果に より、実規模 RP の組立において、要求公差を満足できる見通し を得ることができ、本治工具が適用可能であることを実証した。

\section{3 平板溶接試験}

RPセグメントを接続してRPを組立てる手法として、以 下の方式が考えられる。各々、利点と課題がある。

(1) RPセグメント全体を一括で位置あわせして、その後、 均等に溶接していく方法（一体化組立方式）：利点と して、RPセグメントをD型に配置し、拘束してから溶 接を実施するため、D型形状が得られやすい。課題と しては、各RPセグメントを高精度に配置し、かつ、 レーザー溶接が可能な隙間に調整できるか不明であ る。

（2）RPセグメントを順に付合わせ繋いでいく方法（順次組 立方式）：利点としては、各RPセグメントを順次接続 するためレーザー溶接が可能な隙間調整が容易であ る。一方、課題としては、拘束箇所が溶接部のみとな るため、溶接変形量が大きくなることが懸念される。

そこで、実規模製作時の全体組立方法の指針を得ること を目的として、実規模RP 組立を模擬してD型形状を形成 するRPセグメントを模擬した平板を用意し、上記の組立 手順で試験を実施した。

一体化組立方式の試験手順は、全RPセグメントをあら かじめ測定した基準点を基に配置し、その後、各溶接部の フィッティングを行う。フィッティング時は、各RPセグ メント間のギャップを隙間ゲージで測定し、ギャップが レーザー溶接可能な $0.2 \mathrm{~mm}$ 以下になるように配置する。 RPセグメント同士の拘束はFig. 9 に示す治工具を使用 し、ギャップが大きくなりそうな場合はクランプ等を使用 して調整してからボルト締結した。

一方、順次組立方式では、RPセグメントを順に繋ぎ合 わせる手順で溶接組立を行う。フィッティング時は、溶接 を行うセグメント同士のみを配置し、開先面を調整する。 拘束方法は一体化組立方式と同様の手法とする。 RPセグ
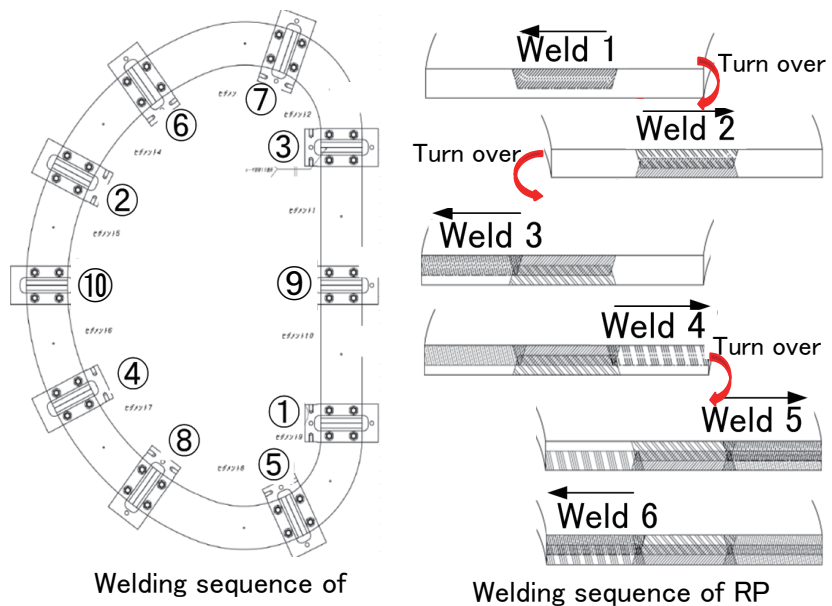

Welding sequence of RP Segument

\section{Weld 6}

Welding sequence of RP

Segument Cross section

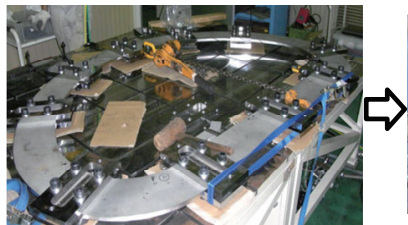

Before welding

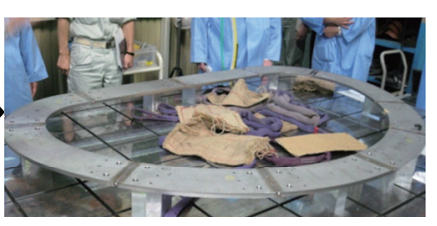

After welding
Fig. 9 D-shaped flat plate welding test. The left upper figure shows the welding sequence of the position on the D-shaped plate. The right upper figure shows the welding sequence in a welding joint. The lower figures are pictures of the sample.

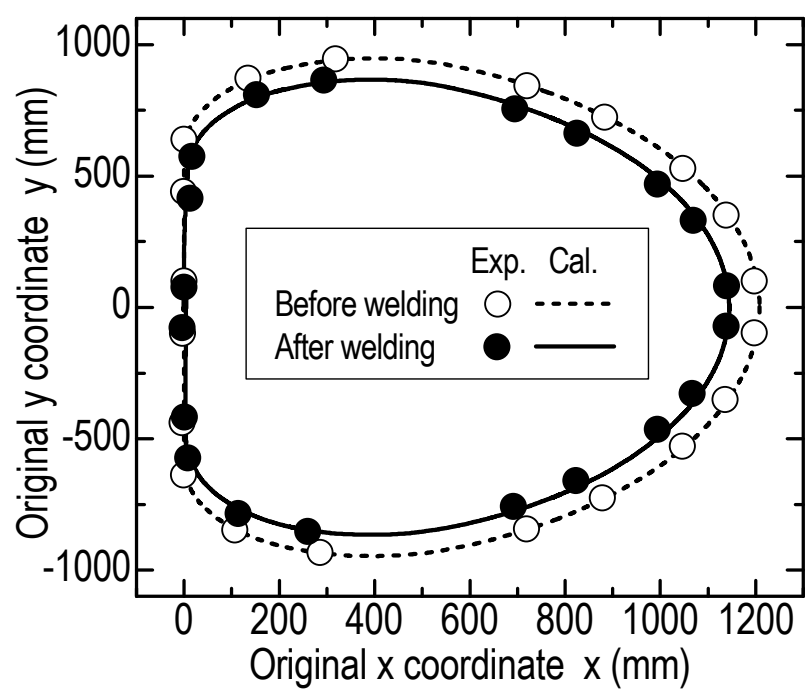

Fig. 10 D-shaped flat plate welding test results. The horizontal and vertical axes denote the coordinates of the position of the $\mathrm{RP}$ contour before welding. The displacement of the RP contour is zoomed by 200 times. (Original $\mathrm{x}$ and $\mathrm{y}$ coordinates mean distance in direction of $\mathrm{x}$ and $\mathrm{y}$ from origin point to measure the RP profile, respectively.)

メント溶接順序は、あるRPセグメント間の断面内のブ ロックを全て溶接してから、次の継手の溶接に移ることと した。 
両方式ともに、断面内の溶接手順については、4.2 項の 22 溶接試験で開発した溶接手順を模擬した手順（Fig. 9） とした。

試験の結果、順次溶接組立方式の場合は、それぞれの継 手溶接時の挙動が不規則であり、面内面外ともに溶接変形 が異なったため、結果として上半分と下半分で変形が異な り、最後のフィッティング時にD型形状に組立てることが できなかった。

順次組立方式と一括組立方式の比較では、順次組立方式 の溶接収縮量平均值が $0.48 \mathrm{~mm}$ に対し、一括組立方式の収 縮量平均值は、それよりも若干小さい $0.41 \mathrm{~mm}$ とった。 角変形量に関しては、順次組立方式に比べて、一括組立方 式の方が変形は小さかった。以上の結果により、実規模 RP組立では、一括溶接組立方式を採用することとした。

また、実規模 RP 組立に向け、溶接変形による形状変化 の評価方法を確立するため、本試験結果を基に、固有歪 ${ }^{6}$ を用いた解析評価も実施した。固有歪法は、溶接部に人工 的に歪を与えて、溶接変形を解析する手法である。本解析 では、簡単のために、溶接継手の軸方向収縮量が $0.4 \mathrm{~mm}$ となるように、軸方向の固有ひずみのみを仮定して、平板 溶接試験体をモデル化して、全体の変形特性を評価した。 その結果、簡易的に固有歪を与えたが、Fig. 10 に示すよう に試験結果と解析結果は概ね一致し、本手法が実機 RP 溶 接変形評価に適用できることが分かった。

\section{5. 実規模 RP 及びCP の試作}

\section{1 機械加工}

実規模 RP 試作 ${ }^{5)}$ に使用する 10 個の RP セグメント製作 における機械加工は、工程上律速段階となるため、機械加 工期間の短縮を主眼に計画を立案した。従って、汎用の機 械加工機で高速化を図る機械加工方法を採用することとし た。一方、これにより加工変形が大きくなることが危惧さ れたが、面外変形については、機械加工後にプレス加工で 矯正して、目標公差を達成する計画とした。

機械加工の結果、8 個の RP セグメントにおいて $1 \mathrm{~mm}$ 以上の面外変形が発生し、目標值である平面度 $1 \mathrm{~mm}$ を達 成することができなかった。そこで、当初の計画通り RP セグメントをプレスによって矯正し、B6 セグメント以外 は、平面度 $1 \mathrm{~mm}$ 以下を達成した。B6 セグメントについ ては、 $\mathrm{N}$ 面、P 面で非対称な溝形状となっているととも に、ターミナル部支持用のブロックが設けられており、 $\mathrm{RP}$ セグメントにおいて特異な形状となっているため、平 面度 $1 \mathrm{~mm}$ を達成する矯正が困難であった（Fig. 11）。さ らに、矯正には長時間を要し、機械加工で高速化を図った が、結果的には効果を相殺してしまう、あるいは、より長 時間を要してしまう結果となった。

実機 RP 製作前には、以上の試作試験の知見を生かし て、平面度 $1 \mathrm{~mm}$ 以下を達成できるように機械加工方法を

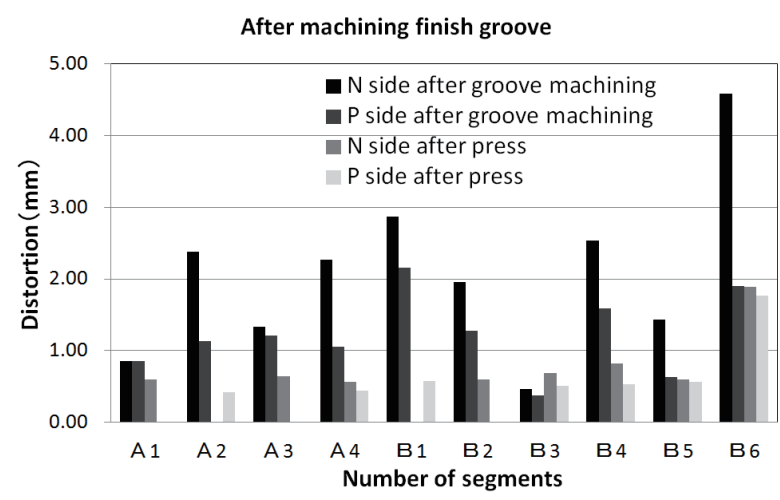

Fig. 11 The measured out-of-plane distortion of the RP.

最適化する計画である。また、最近の小規模試作の結果か ら、加工変形の小さい機械加工方法を開発しており、今 後、その実証を行う計画である。

\section{2 組立方法}

実規模 RP（Fig. 12）の組立は、以下の手順で実施し た：1）RP セグメントを配置するための高さ調整の治具を 設置、2）製作した 10 個の RP セグメントを D 型に配置、 3）フィッティング治工具による RP セグメントの位置、 隙間調整、4）位置調整を行った RP の位置計測、5）仮付 け溶接、6）本溶接、7）最終位置計測。

\section{3 組立結果}

最終のRP位置計測は、溶接完了後、拘束治具を開放し た状態で実施した。その結果、Fig. 13に示すように、輪郭 度は要求公差である $2 \mathrm{~mm}$ 達成した。

また、並行して実施した22溝溶接試験（4.2項）で得ら れた $0.5 \mathrm{~mm}$ の溶接収縮に対して、平板溶接試験と同様に

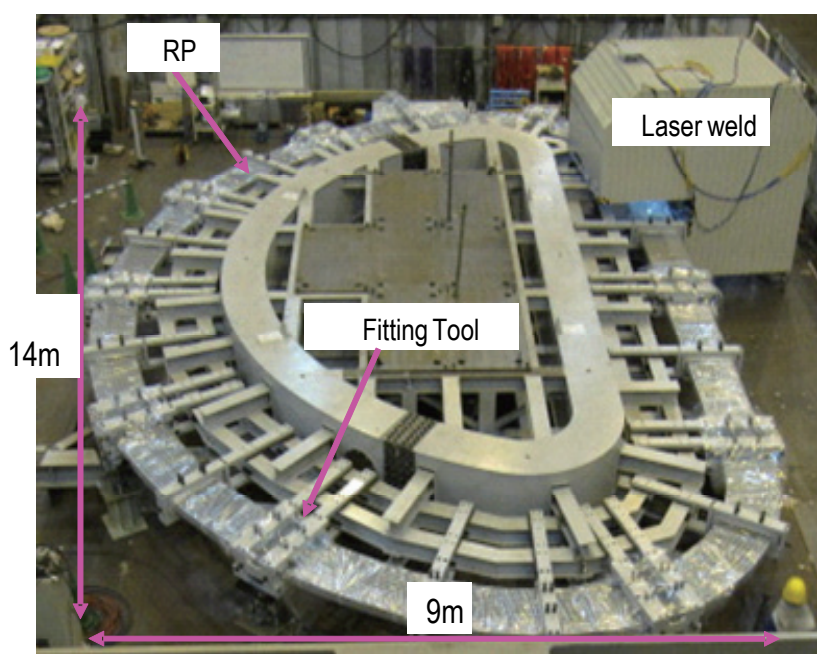

Fig. 12 Full-scale RP trial test. The RP is fixed by using constraint tooling. The fitting tool restraint the ends of each section for butt welding. 
約 $80 \%$ の収縮量である $0.4 \mathrm{~mm}$ の溶接収縮を与える固有ひず みを仮定して、実規模RPの溶接変形量を解析した。その 結果、測定結果と解析值はほぼ一致し、固有ひずみを用い た解析方法が、実機製作における溶接変形評価に適用でき ることが確認できた。

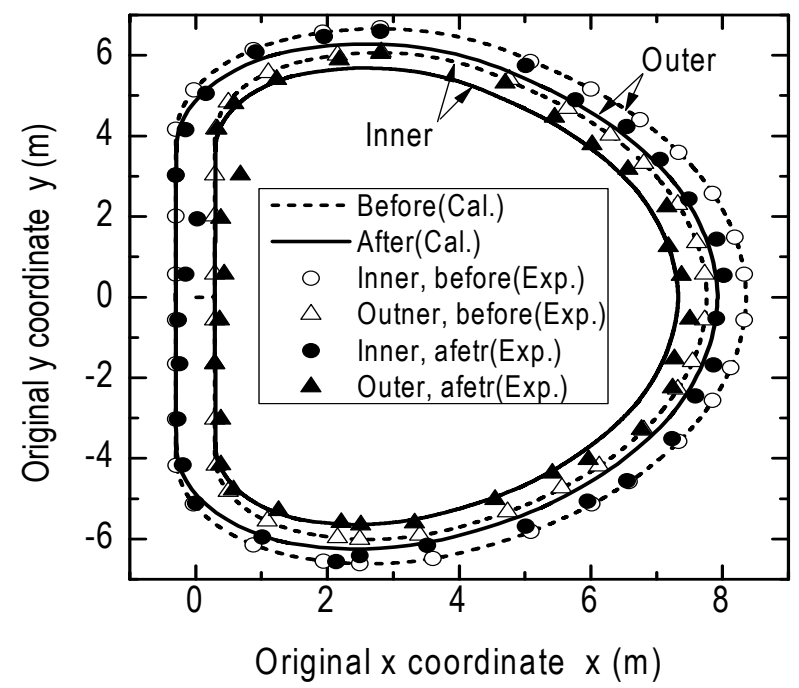

Fig. 13 The measured and calculated inner and outer contours of the full-scale RP before and after welding. The circles and triangles are for the inner and outer contours. The displacement is zoomed by 500 times. (Original $\mathrm{x}$ and $\mathrm{y}$ coordinates mean distance in direction of $\mathrm{x}$ and $\mathrm{y}$ from origin point to measure the RP profile, respectively.)

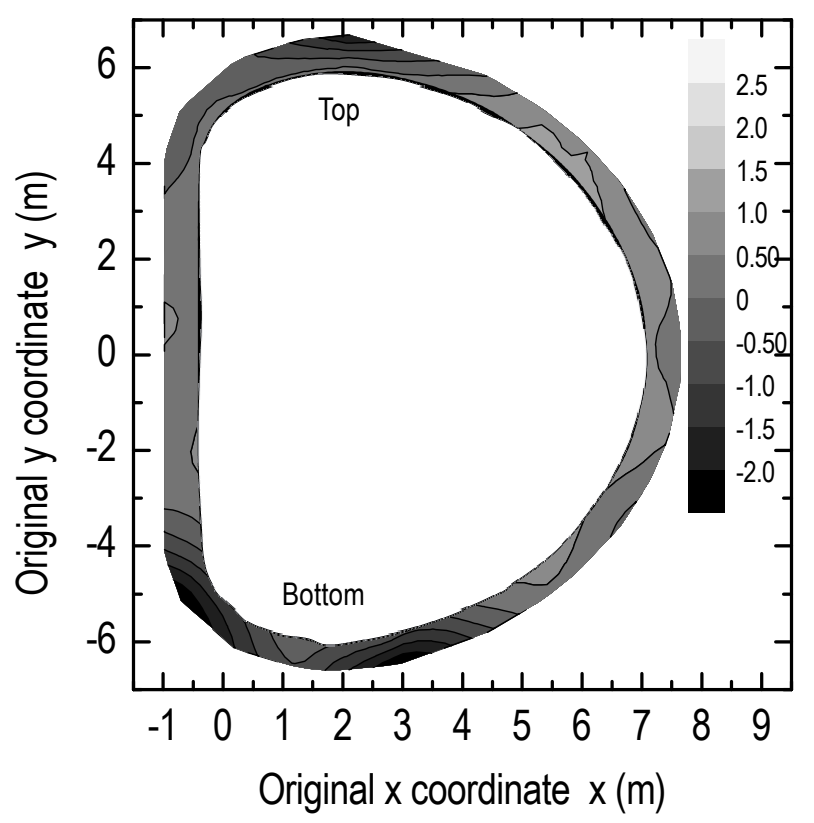

Fig. 14 The measured distortion of the full-scale RP after welding. (Original $\mathrm{x}$ and $\mathrm{y}$ coordinates mean distance in direction of $\mathrm{x}$ and $\mathrm{y}$ from origin point to measure the RP profile, respectively.)
実規模 RP の平面度は、Fig. 14 に示すように、RP の Top 側と Bottom 側以外では、大きな変形は見られなかっ た。Top 側と Bottom 側の変形については、支持治具が配 置されていない部分があったため、自重の影響を受けて、 長波長の面外変形が生じたものと推察される。このため、 支持治具の配置を最適化することにより、長波長の面外変 形は現実的には問題とならないことが期待できる。これ は、DPを積層する場合と同様に、RPを十分に短い間隔で 支持することで平面度は改善できることを意味し、長波長 の面外変形は治具を改良することで相殺でき、実機 RP 製 作における平面度 $1 \mathrm{~mm}$ を達成できるとものと期待でき る。

\subsection{CP の試作結果}

$\mathrm{CP}$ の製作方法 ${ }^{7}$ は 3 種類の方法があり、直線部の CP は、 ビレットを熱間圧延及び冷間引抜加工して製作し、一様曲線部 の $\mathrm{CP}$ は、前記の直状 $\mathrm{CP}$ を 3 点ローラー曲げ加工機で曲げ 加工寸る方法で製作した。また、曲率が遷移する CP は、板材 を機械加工する方法で製作した。

製作の結果、直線部の冷間引抜 CP は、断面形状の寸法公 差 $\pm 0.1 \mathrm{~mm}$ 以下を達成した。一様曲率部の曲げ加工 CP は、 曲率半径の精度 $\pm 0.3 \mathrm{~mm}$ 以下を達成した。しかし、曲げ加工 により、CP 内径側断面の $\mathrm{CP}$ 高さの厚みが $0.2 \mathrm{~mm}$ 程度厚くな り、一部寸法公差を達成することができなかった。これは、左右 対称の金型から冷間引抜して CP 製作したためであり、左右非 対称な金型を製作することにより対応可能と考えられる。

曲率遷移部の機械加工で製作した CP については、寸法公 差を満足したが、加工変形による撓みが生じた。これについて は、僅かな力で撓みを矯正できるので、 RP に CP を嵌めこむこ とは可能である。

\subsection{CP 嵌め合い試験}

$\mathrm{RP}$ とCPの嵌め合い試験（Fig. 15）を実施した結果、約3 割りのCPが嵌め合うことができず、特にB6セグメントが 支配的であった。原因として、B6セグメントセグメント については、5.1項の記載のとおり、矯正を実施したにも 拘らず、平面度 $1 \mathrm{~mm}$ 達成することができず、面外変形 が残り、溝幅の寸法に変形が生じたことが主な要因であ

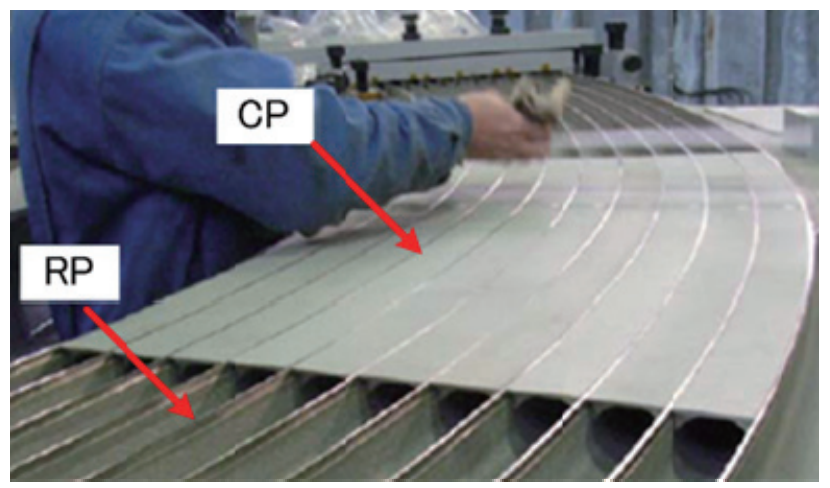

Fig. 15 Fitting confirmation of the CP. 
る。また、RPと CPの嵌め合い部の設計寸法公差に尤度が 無いことも要因の一つである。

このため、実機製作の前に平面度 $1 \mathrm{~mm}$ 以下を達成でき るように機械加工方法を最適化するとともに、RPとCPの 嵌め合い部の寸法公差について本試験結果を基に反映する 必要がある。また、 RPの溝とCPを溶接するギャップは、 一部、 $0.5 \mathrm{~mm}$ 以上なったが、手でCPを位置調整するこ とにより、レーザー溶接が可能な $0.5 \mathrm{~mm}$ 以下にギャップ を調整することが可能であった。

\section{6. 結論}

TF コイル開発の一環として, RP 及び CP 試作試験を実施し, 以下の結論を得た。

(1) RP の溶接試験で、1）継手部治工具の開発、2）溶接 変形量の把握、3) 数 $\mathrm{mm}$ の高精度での溶接変形量の 抑制を達成した。

(2) 平板試験の結果を用いて、レーザー溶接による変形 量を解析で評価した。実規模 RP における溶接変形 の測定結果と本手法で解析した結果は概ね一致して おり、本解析方法の有効性が確認できた。

（3）実規模 RP 試作では、高精度な製作公差を達成し、実 機 RP 製作に目途を立てることができた。

（4）溶接部に確認された溶接割れは、溶接条件に依存す ることが確認できた。日欧で得られた試作の成果を 基に、最も合理的な溶接手法を決定し、実機 RP 製 作を進める計画である。

\section{参 考 文 献}

1) N. Koizumi, et al.: "Development of ITER Toroidal Field coils in Japan,” TEION KOGAKU 47 (2012) 135-139 (in Japanese) 小泉徳潔ら：「日本における ITER トロイダル磁場コイルの 開発」, 低温工学 47 (2012) 135-139

2) N. Koizumi, et al.: "Results of ITER Toroidal Field coil cover plate welding," TEION KOGAKU 47 (2012) 186-192 (in Japanese) 小泉徳潔ら：「ITERトロイダル磁場コイルのカバー・プレー 卜溶接試験」, 低温工学 47 (2012) 186-192

3) JSME (The Japan Society of Mechanical Engineers), Codes of Fusion Facilities -Rules on Superconducting Magnet Structure -, JSME S KA 1-2008, Maruzen (2008)

4) K. Takano, et al.: "Development of manufacturing technology of radial plate for ITER TF coil," Abstracts of CSJ Conference $\mathbf{8 3}$ (2010) 42

高野克敏ら：「ITER TFコイル ラジアル・プレートの製作技 術開発」, 第 83 回秋季低温工学・超電導学会講演概要集 (2010) 42

5) K. Takano, et al.: "Results of ITER TF coil full-scale radial plate trial manufacture," Abstracts of CSJ Conference 84 (2010) 102 高野克敏ら：「ITER TFコイル実規模ラジアル・プレート試作 結果」, 第84回春季低温工学・超電導学会講演概要集 (2011) 102

6) M. Mochizuki, et al.: "Numerical analysis of welding residual stress and its verification using neutron diffraction measurement," ASME Trans. J. Eng. Mater. Technol. 122 (2000) 98-103

7) K. Takano, et al.: "Development of manufacturing technology of radial plate and cover plate for ITER TF coil," Abstracts of CSJ Conference 80 (2009) 122

高野克敏ら：「ITER TFコイル ラジアル・プレート及びカ バー・プレートの製作技術開発」, 第80回春季低温工学・超 電導学会講演概要集 (2009) 122

高 野 克 敏 1974 年 5 月生。1993 年より日本原子力研究 所（現日本原子力研究開発機構）勤務。主に大型超伝導コイル及 び極低温構造材料の研究 - 開発に従事。低温工学・超電導学会会 員。

小 泉 徳 潔 1964 年 5 月 8 日生。1988 年早稲田大学理工 学部機械工学科卒業。1990 年同大学院機械工学専攻修了。同年 日本原子力研究所 (現日本原子力研究開発機構) 勤務。核融合炉 用超電導導体及びコイルの研究・開発に従事。低温工学・超電導 学会、電気学会、プラズマ・核融合学会会員。工学博士。

清 水 辰 也 1963 年 11 月生。1987 年より日本原子力研 究所（現日本原子力研究開発機構）勤務。核融合炉用超電導導体 及びコイルの解析に従事。

中 嶋秀夫 1956 年 1 月生。1981 年より日本原子力研究 所に入所。現在、日本原子力研究開発機構 ITER 超伝導磁石開発 グループリーダー。主に、大型超伝導コイル及び極低温用構造材 料の研究開発に従事。低温工学・超電導学会、日本機械学会、日 本鉄鋼協会、日本保全学会会員。

江 崎康一 1979 年 8 月生。2004 年九州大学大学院先端 エネルギー理工学専攻修士課程修了。同年 4 月 (株) 東芝入社。現 在、京浜事業所機器装置部生産技術担当。主として核融合機器、 超伝導応用機器の開発に従事。プラズマ・核融合学会会員。

長 本 義 史 1980 年 11 月 3 日生。 2003 年東京大学工学部 システム創成学科卒業。2005 年同大学院工学系研究科システム 量子工学専攻修士課程修了。同年 (株) 東芝勤務。主に超電導磁石 設計・開発に従事。

牧野 吉 延 1958 年 11 月 16 日生。1984 年大阪大学大学 院溶接工学専攻修了。同年 (株) 東芝入社。現在、主にレーザビー ムを用いた製造技術開発に従事。溶接学会会員。 